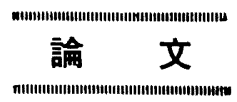

UDC $669.15^{\prime} 71^{\prime} 786-192: 546.621^{\prime} 171.1: 621.785 .363$

\title{
加工した高純度 $\mathrm{Fe}-\mathrm{Al}-\mathrm{N}$ 合金中の $\mathrm{AlN}$ の析出*
}

\author{
小川 陸郎** ·福塚 淑郎** 一八 芳郎*** \\ Precipitation of AlN in Cold-worked High Purity Fe-Al-N Alloy \\ Rikuo Ogawa, Toshiro FuKutsuka, and Yoshiro YaGI
}

\begin{abstract}
Synopsis :
The precipitation process of AlN in a cold worked high purity $\mathrm{Fe}-0.09 \mathrm{Al}-0.01 \mathrm{~N}$ alloy was studied. The alloy was made from a zone refined high purity iron bar $(>99.99 \%)$ and an $\mathrm{Al}-\mathrm{Fe}$ alloy by embedding the latter at an interval along the specimen axis and zone refining the composite in a $\mathrm{N}_{2}-\mathrm{H}_{2}$ atmosphere. The alloy was subsequently quenched into ice water after solution treatment of $1250^{\circ} \mathrm{C} \times 1 \mathrm{hr}$ and cold drawn $68.6 \%$ at room temperature. The electrical resistivities of the wircs, annealed isochronally and isothermally, were measured in liquid nitrogen, and the precipitates of AIN were examined by electron microscope extraction replica method. The results obtained were as follows;

1) A large decrease of the electrical resistivity was observed at the temperature range from $450^{\circ} \mathrm{C}$ to $620^{\circ} \mathrm{C}$, which was attributed to the precipitation of AIN. This temperature range was lower by about $100^{\circ} \mathrm{C}$ than that in the not-strained specimens.

2) The precipitation processes under about $580^{\circ} \mathrm{C}$ could be described as a first order reaction after a respective certain period of time, for which the activation energy of reaction was $58 \mathrm{Kcal} / \mathrm{mol}$, which suggested that the precipitation of AlN in the cold worked matrix was controlled by the diffusion of $\mathrm{Al}$ in $\alpha$-iron.

3) The cubic lattice structure of AIN was occasionally observed in the early stage of precipitation, but most of the precipitates observed in the high purity specimens used here were identified to be AlN of the hexagonal lattice structure.
\end{abstract}

(Received July 1, 1971)

\section{1. 緒言}

アルミキルド鋼板の良好な樑絞り性は鋼中の AIN の 析出挙動と密接な関係があることが知られてから, AIN の析出挙動と再結晶集合組織との関連について数多くの 実験がなされてきた1)ー6). 回復・再結晶洔に AIN を析 出させると $\{111\}$ 面が板面に平行な再結晶集合組織が 得られるが，これに対して有効な AlN は析出のごく初! 期の段階のもので AIN の結晶体とは確認できず, 微小 な AlN または AlN の pre-precipitation cluster であ るといわれている2）6．再結晶過程を詳細に観察し，こ のような析出が起こるときの再結晶機構を明らかにしよ うとする立場の研究は最近とくによく行なわれ, 現象的 にはかなりの点が明らかにされてきた7) 10). X線のline profile の観察から AlN の析出は回復を遅らせることが 報告され, 再結晶機櫵について種々議諭されている11). しかしその機構の詳細についてはまだ明確な結論は得ら れていない, また AIN の析出挙動については, 最近花

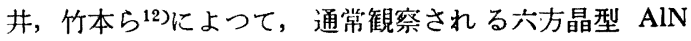
の前に立方晶型 AIN が析出することが報告された.こ れらの多くの実験は実用アルミキルド鋼によるものが多 く, 不純物の効果は割合に無視されている.わずかに最 近市山らによつて炭素の存在によりAlNの析出が変化す ることが報告されているにすぎない7，そこで 本研究で は他の不純物の影響を除くため，带域精製した高純度鉄 を素材にして Fe-Al-N希薄合金を作り，その合金中での

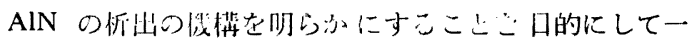

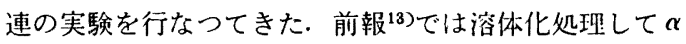
域で析出させたときの結果から, AlN の析出が $\alpha$ 鉄 中 での $\mathrm{Al}$ の拡散によつて律速され, 初期浱度の異なる 2 次反応として示されることを報告した．本報では続いて 溶体化処理した試料を冷間加工し, 加工組織中で AIN

* 昭和 45 年 10 月本会講演大会にて発表 昭和46年 7 月 1 日受付

**（株）神戸製鋼所浅田基礎研究所

****（株）神戸製鎆所浅田基濋研究所工博 
Table 1. Example of chemical composition of zone-refined iron.

\begin{tabular}{c|c|c|c|c|c|c|c|c|c|c|c|c|c|c|c|c|c|c}
\hline & $\mathrm{B}$ & $\mathrm{Mg}$ & $\mathrm{P}$ & $\mathrm{S}$ & $\mathrm{Ca}$ & $\mathrm{Ti}$ & $\mathrm{V}$ & $\mathrm{Cr}$ & $\mathrm{Mn}$ & $\mathrm{Co}$ & $\mathrm{Ni}$ & $\mathrm{Cu}$ & $\mathrm{Zn}$ & $\mathrm{Ge}$ & $\mathrm{As}$ & $\mathrm{C}$ & $\mathrm{O}$ & $\mathrm{N}$ \\
\hline $\mathrm{ppm}$ & 0.07 & 0.2 & 2 & 1 & 4 & 0.07 & 0.06 & 4 & 3 & 24 & 1 & 12 & 0.2 & 0.1 & 4 & $<10$ & $<10$ & $<3$ \\
\hline
\end{tabular}

を析出させた場合の結果について報告する.

\section{2. 試料および実験方法}

素材は電解鉄を原料とした真空溶解純鉄の棒を湿潤水 素之乾燥水素中で交互に 5 回帯域精货して得られた純度 $99 \cdot 99 \%$ 以上の高純度鉄で, その分析例を Table 1 K 示す.

この高純度鉄の丸棒 $(15 \mathrm{~mm} \phi)$ に等間隔に穴をあけ， その中に $4.96 \% \mathrm{Al}-\mathrm{Fe}$ 母合金 $(99 \cdot 999 \% \mathrm{Al}$ と高純度鉄 をアルゴンガス中でアーク溶解して作つた.）を目標成 分になるように等量ずつ埋め込み，それを $\mathrm{N}_{2}+\mathrm{H}_{2}$ 混合 ガス中でさらにもう一度带域溶融することにより $\mathrm{Al}$ と $\mathrm{N}$ 同時に添加した. 得られた試料の化学成分は $\mathrm{Al}$ が $0.09 \mathrm{wt} \%$ ， N が 0.01 wt\% であつた.この試料を鍛 造し, 厚さ $6 \mathrm{~mm}$ の板材とし, これより切り出した角 棒をスェージ加工および伸線加工して, $1 \cdot 82 \mathrm{~mm} \phi$ の線 を得た. この線を石英管中に $100 \mathrm{mmHg}$ の $\mathrm{He}$ ガスと ともに封入し，溶体化処理として $1250^{\circ} \mathrm{C} \times 1 \mathrm{hr}$ の加熱 後水水中に焼入れ, 直ちに常温で $68.6 \%$ の伸線加工を 施した．この試料に等時焼鈍，等温焼鈍を施し，電気抵
抗の変化，再結晶分率の变化を測定した．等時焼鈍のた めの熱処理は $250^{\circ} \mathrm{C}$ まではオイルバス， $250^{\circ} \mathrm{C}$ 以上で は真空中で焼入れ可能な堅型真空焼入れ炉を使用した。 等温焼鈍には昇温速度を上げるためにソルトバスを使用 し, 試料の酸化を防ぐため, 細い石英管に試料を $\mathrm{He}$ 力 スとともに封入できる器具を作つた。 室温より $700^{\circ} \mathrm{C}$ までの昇温時間および $700^{\circ} \mathrm{C}$ から $0^{\circ} \mathrm{C}$ までの泠却時 間は約 $30 \mathrm{sec}$ であつた，電気抵抗は液体 䇪素中で通常 の4端子法により，電位差計または Digital Voltmeter (YEW Type 2805) を用いて測定した. また $100 \mathrm{~min}$ を越える長時間の等温焼鈍には横型の真空加熱炉を用い た. 再結晶分率の測定は長さ方向の断面を光学顕微鏡で 観察し，通常の点算法によつた. さらに一部の試料につ いて抽出レプリカ法による析出物の電湿観察を行なつ た. 抽出レプリカは花井, 竹本らが立方晶AIN の観察に 用いた方法12てで行なつた。

\section{3. 実 験 結 果}

\section{$3 \cdot 1$ 電氮抵抗}

溶体化处理した後 $68 \cdot 6 \%$ の伸線加工した試料に $10^{\circ} \mathrm{C}$

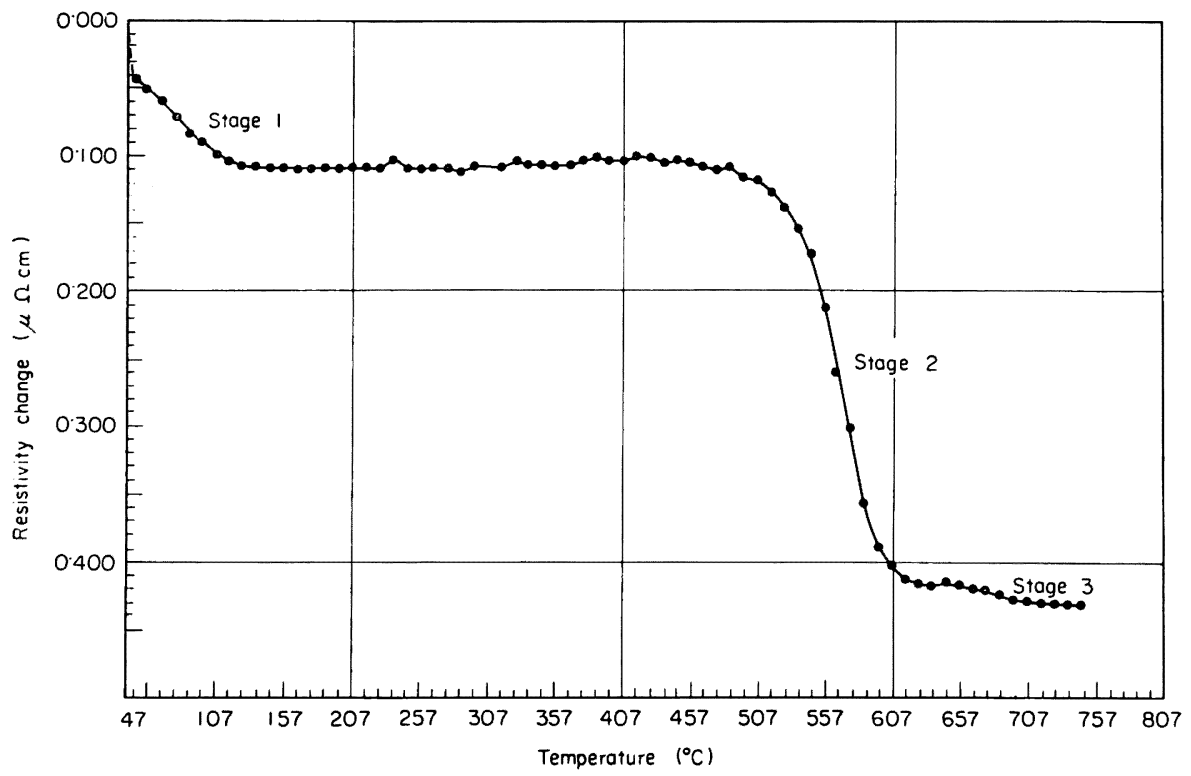

Fig. 1. $10^{\circ} \mathrm{C}-10 \mathrm{~min}$ isochronal annealing curve of cold-worked $\mathrm{Fe}-0 \cdot 09 \mathrm{Al}-\mathrm{N}$ alloy after solution treatment. 
$/ 10 \mathrm{~min}$ の等時焼鈍を施したときの電気抵抗変化の結 果を Fig. 1 に示す. 四は加工直後の電気抵抗値を基 準にして，焼鈍による抵抗值の变化を示したもので $750^{\circ} \mathrm{C}$ 亡でに 3 つの stage が存在することがわかる．第 1 は $130^{\circ} \mathrm{G}$ までに終わる stage (stage 1 )，第 2 は約 $450^{\circ} \mathrm{C}$ より始まり $620^{\circ} \mathrm{C}$ で終わる stage (stage 2 ), 第 3 は $670^{\circ} \mathrm{C}$ より $720^{\circ} \mathrm{C}$ までに起こる小さな stage（stage 3 ) である. stage 1 は固溶したNが転位にとらえられ る歪時効と加工によつて導入された各種の点欠陥の消滅 が起こる stage であろう. stage 2 は前報で報告したよ うに AlN の析出による stage と考沈られる. stage 3 は加工していない試料には観察されなかつたもので再結 晶による stage であろう.このほかに加工組織の回復に よる stage，正時効により転位上に析出した $\mathrm{N}$ の相一 の復帰による stage などが考えられるが，これらは上記 の stage に重なつて起こつているものと思われる. stage 1 が終わつて stage 2 が始まるをで電気抵抗は約 0.01 $\mu \Omega \mathrm{cm}$ 增加する. これは転位にとらえられた $\mathrm{N} か ゙$ ，部母 相人再固溶するためと思われるが，抵抗值からの推定で はその量はごく微量である. 前報で報告したごとく加工 していない試料では，AIN が析出する前には，より低 温で析出した鉄窒化物は完全に再固溶し, 電気抵抗値は 焼入れ状態の值にもどつたか，強加工した試料では, Fir. 1 に示すように, 電気抵抗は加工直後の值にはもど らデ，ごくわずか上昇するだけで stage 2 が始まる。こ のことはNは大部分転位にとらえられたまま， AlN の析
出が起こることを示しているものと思われる.

stage 2 が起こる各温度で等温焼鈍したときの電気抵 抗の変化を Fig. 2 に示す. 加工直後の電気抵抗值を基 淮にして各熱処理を施したときの抵抗值との差を処理時 間に対して示してある. Fig. 2 の等温燒鈍曲線にも 3 つ の stage が存在する.どの温度の焼鈍でもまず電気抵抗 は小さく低下する，そして一定值が続いて次の大きな低 下がある，この大きな低下が終わり，そのまま焼鈍を綂 けると電気抵抗はさらに低下してくる，焼鈍時間 $1 \mathrm{~min}$ 末でに起こる最初の stage は Fig. 1 の stage 1 に対応 するものであり, それらの低下量もほぼ等しい. AIN の 析出に対応すると考えられる次の大きな電気抵抗の低下 は $527^{\circ}, 557^{\circ}, 577^{\circ} \mathrm{C}$ と温度の上昇につれて早くなるが， さらに $607^{\circ}, 627^{\circ} \mathrm{C}$ と温度が上昇するとむしろおそくな る. 等温烧䤞に上る AlN の析出は加工組織の回復・再 結品と競合する，焼鈍温度が上昇すると回復・再結昆が AIN の析出よりさきに起こるた好歪のない母相中での 析出となり，析出の site が減少するため，析出がおそく なるものと考えられる．さらに焼鈍時間を長くすると電 気抵抗は一定值になつた後，しだいに低下しはじめる が，これは試料中に残存する溶質 $\mathrm{Al}$ の内部酸化が徐々 に起こるためと思われる.

\section{$3 \cdot 2$ 再結晶分率}

加工組織の回復・再結晶と AlN の析出との間の関係 を明らかにするため, 再結晶分率の測定を行なつた，比 較用の試料として $1250^{\circ} \mathrm{C} \times 1 \mathrm{hr}$ の溶体化処理後 $707^{\circ} \mathrm{C}$

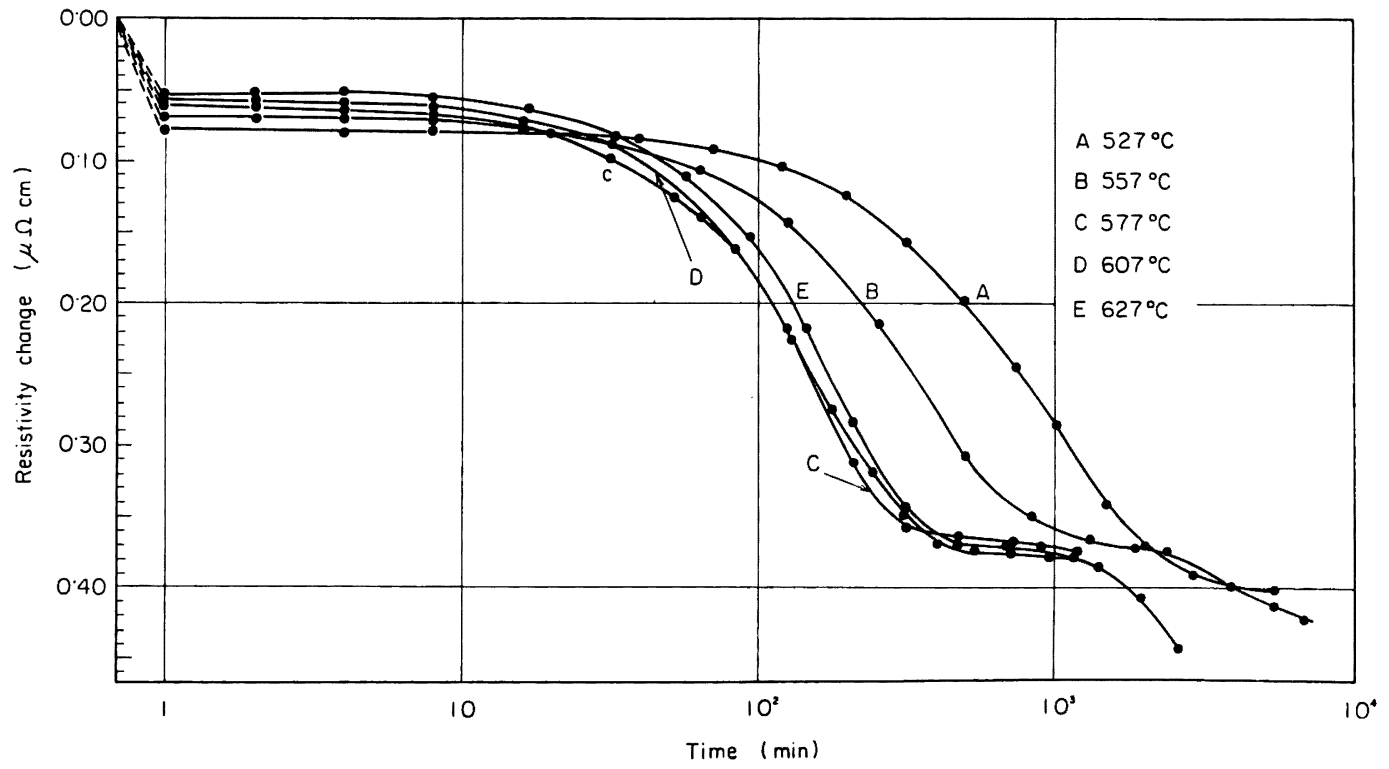

Fig. 2. Isothermal-annealing curves of cold-worked Fe-0.09Al-N alloy. 


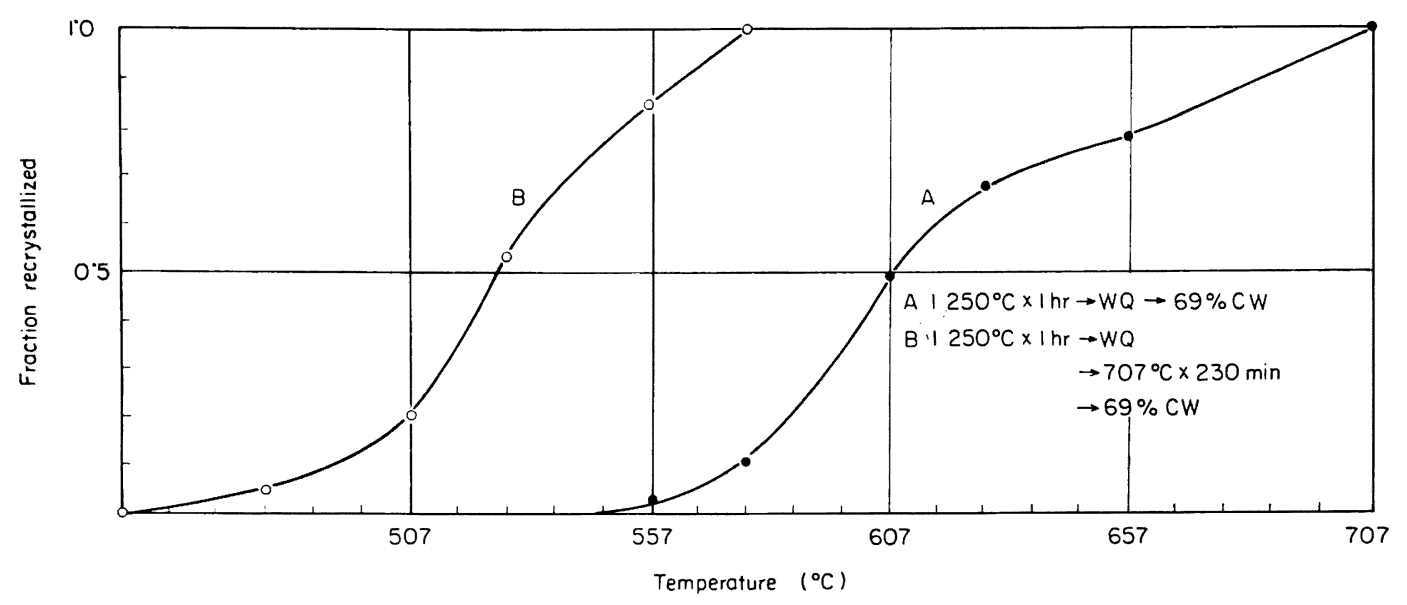

Fig. 3. $30 \mathrm{~min}$ isochronal recrystallization curves.

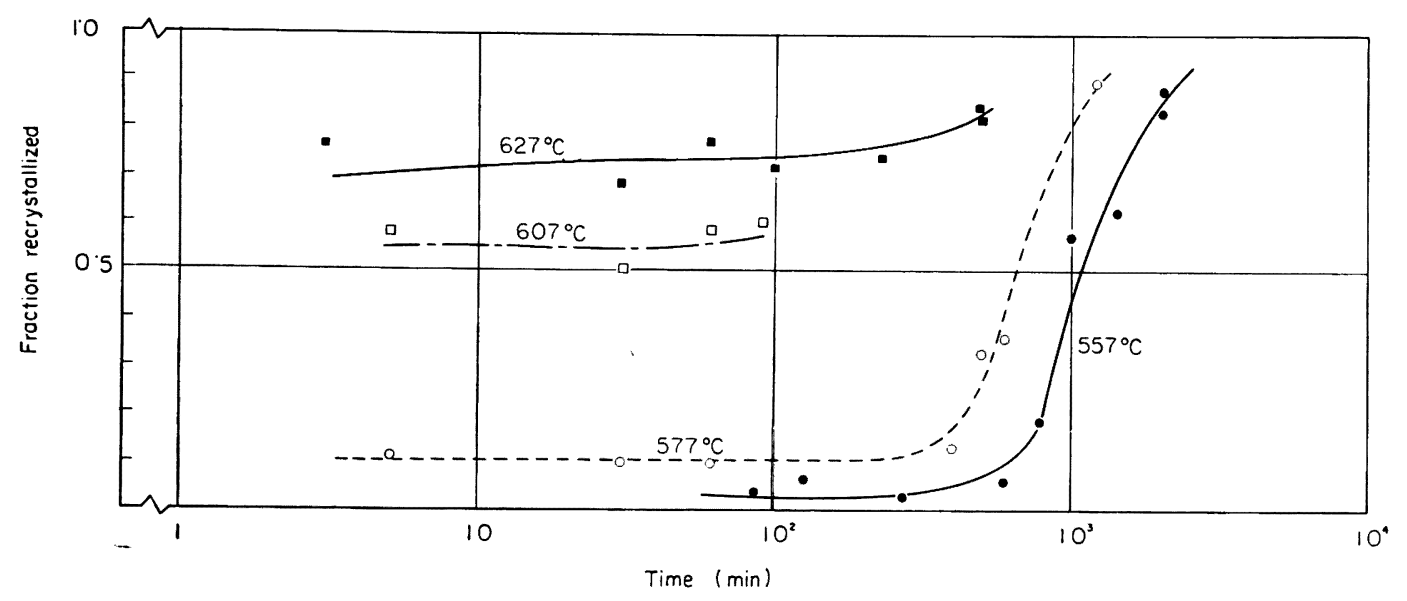

Fig. 4. a) Isothermal recrystallization curves of specimen A $\left(1250^{\circ} \mathrm{C} \times 1 \mathrm{hr} \rightarrow \mathrm{WQ} \rightarrow 69 \% \mathrm{CW}\right.$ ).

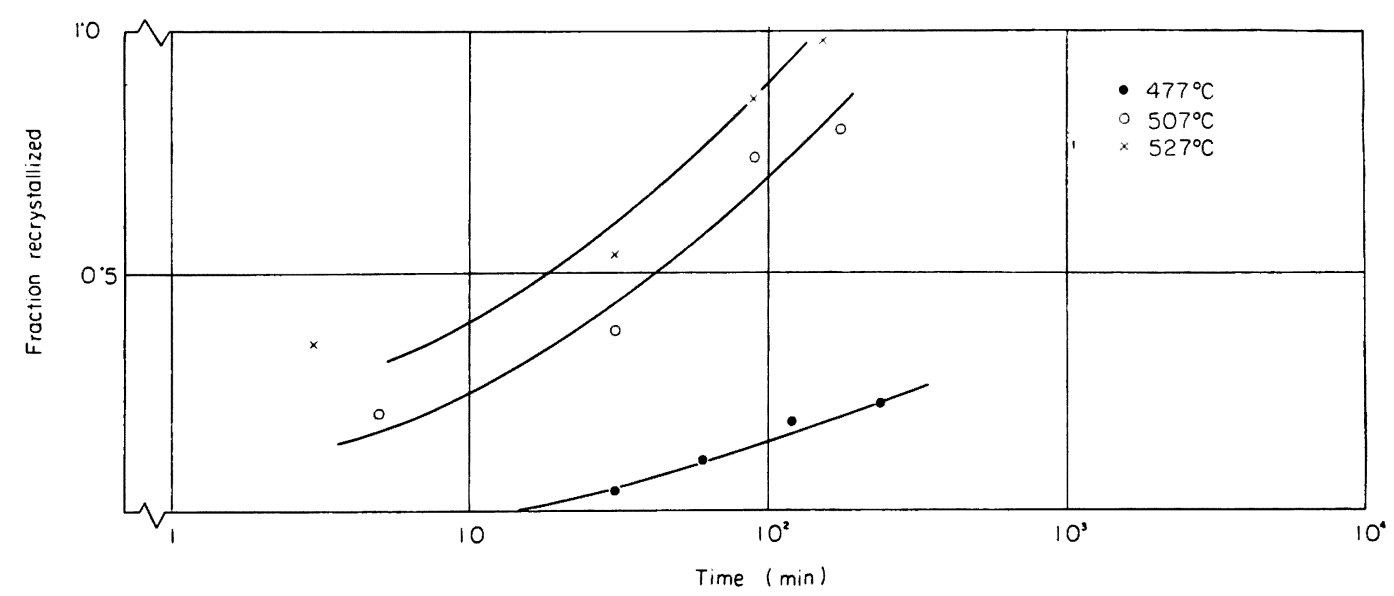

Fig. 4. b) Isothermal recrystallization curves of specimen $B\left(1250^{\circ} \mathrm{C} \times 1 \mathrm{hr} \rightarrow W Q\right.$ $\rightarrow 707^{\circ} \mathrm{C} \times 230 \mathrm{~min} \rightarrow 69 \% \mathrm{CW}$ ). 
$\times 230 \mathrm{~min}$ の析出処理を加えた後, 常温で $68.6 \%$ の伸 線加工を施した試料（B）を用意した。 これらの試料を 各温度で $30 \mathrm{~min}$ 保持したときの 再結晶分率を Fig. 3 に示す. 加工前に析出処理を施していない試料 (A) で は再結晶のおくれは顕著である. 実用アルミキルド鋼で いわれている, AlNが再結晶をおくらせる効果は, この ような高純度 $\mathrm{Fe}-\mathrm{Al}-\mathrm{N}$ 合金でも同様であることがわか る. Fig. 4 a)，b）に等温焼鈍における再結品分率の変 化を示す. 各温度ともに最初の数分間である量の再結晶 がおこり，その後ある時間可結晶は抑えられる. Fig. 2 の等温焼鈍曲線と比較して，析出が起こつている間はど の温度においても再結晶は抑えられることがわかる．析 出が 90\% 進んだと思われる時間より残りの部分が再結 晶する.すなわち， $557^{\circ} \mathrm{C}$ では数\%再結晶した状態で抑 えられ， $577^{\circ} \mathrm{C}$ では $10 \%, 607^{\circ} \mathrm{C}$ では $60 \%, 627^{\circ} \mathrm{C}$ では $70 \%$ が最初の数分で再結晶し, 残りの部分の再結
晶は析出の起こつている間は抑えられる.したがつて， Fig. 2 の等温焼鈍曲線で， $577^{\circ} \mathrm{C}$ 以上に打ける AIN の 析出が，より低温における焼鈍よりもむしろおそくなつ てくるのは, 最初の数分で数 $10 \%$ 再結晶し, そのため AlN の析出のための site が減少したためと思われる. また再結晶が最初の数分で進行し，その後進行しないの は, AlN の析出段階において，ごく初期の段階から再 結晶の進行を阻止するのに効果があることがわかる.こ のA材に比較して, 加工前に析出処理定した試料 Bでは 再結晶はなめらかに進行する.これらの試料の代表的な 光学顕微鏡写真を Photo. 1 に示寸. 析出によつて再結 晶が抑えられた試料では，再絬唱が起こると線の長さ方 向にのびた再結晶粒が得られる．また粒径も大きい、い ずれの場合でも析出が $90 \%$ 以上起こつた後に，抑えら れていた加工組織は再結晶する. 析出過程の後半では析 出物の成長が起こり，ある大きさ以上になると，抑止效

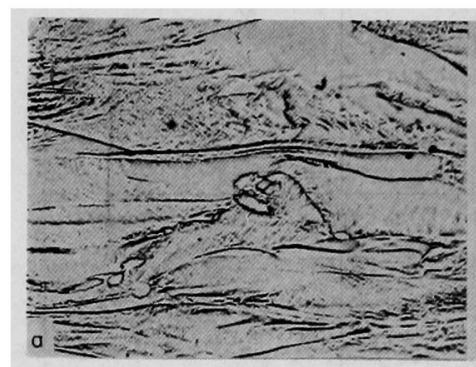

Specimen $\mathrm{A}$ at $557^{\circ} \mathrm{C}$ a) $87 \mathrm{~min}$

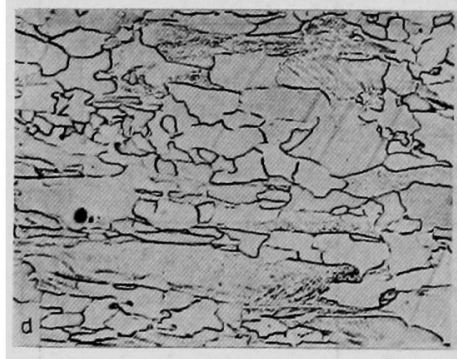

Specimen $\mathrm{A}$ at $627^{\circ} \mathrm{C}$ d) $3 \mathrm{~min}$

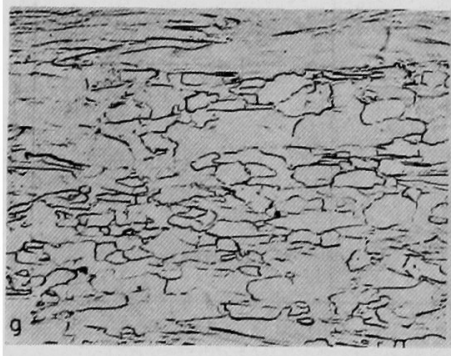

Specimen $B$ at $527^{\circ} \mathrm{C}$ g) $3 \mathrm{~min}$

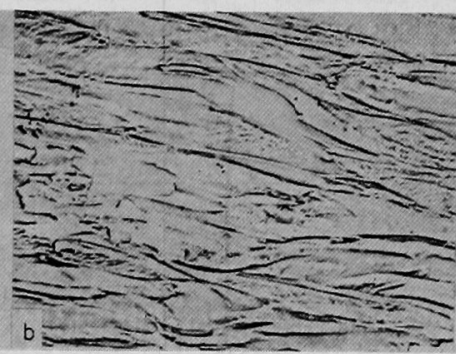

b) $500 \mathrm{~min}$

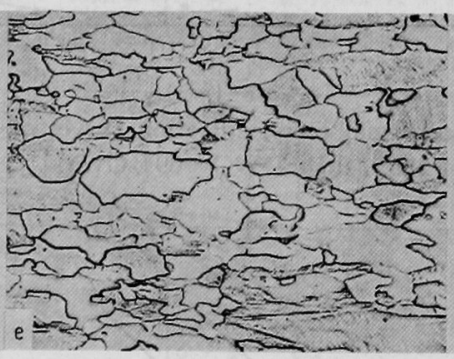

e) $60 \mathrm{~min}$

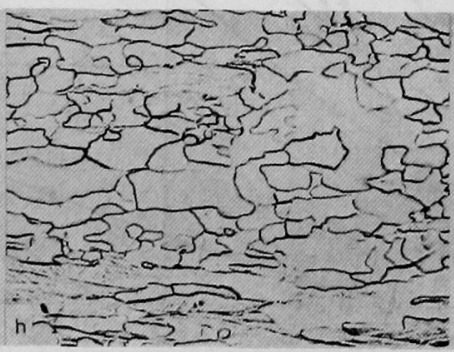

h) $30 \mathrm{~min}$

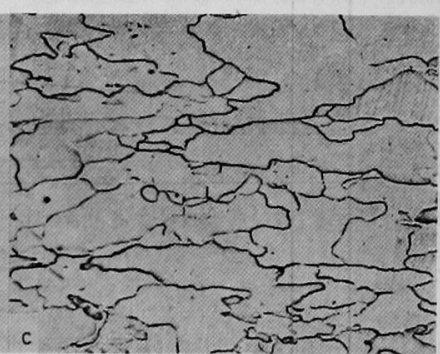

c) $2042 \mathrm{~min}$

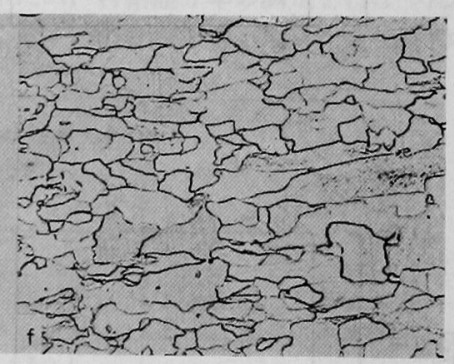

f) $230 \mathrm{~min}$

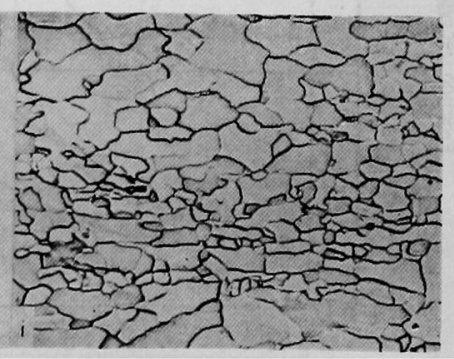

i) $150 \mathrm{~min}$

Photo. 1. Microstructures of specimen A $\left(1250^{\circ} \mathrm{C} \times 1 \mathrm{hr} \rightarrow W Q \rightarrow\right.$ Cold drawn $)$ and specimen $B$ $\left(1250^{\circ} \mathrm{C} \times 1 \mathrm{hr} \rightarrow \mathrm{WQ} \rightarrow 707^{\circ} \mathrm{C} \times 230 \mathrm{~min} \rightarrow\right.$ Cold drawn $) . \quad(3 / 5) \times 90$ 
Table 2. Chemical compositions of hot band.

\begin{tabular}{c|c|c|c|c|c|c|c|c|}
\hline & $\mathrm{C}$ & $\mathrm{Mn}$ & $\mathrm{Si}$ & $\mathrm{P}$ & $\mathrm{S}$ & $\mathrm{Al}$ & $\mathrm{O}$ & $\mathrm{N}$ \\
\hline Hot band & 0.023 & 0.28 & 0.040 & 0.005 & 0.009 & 0.046 & 0.0062 & 0.0072 \\
\hline
\end{tabular}

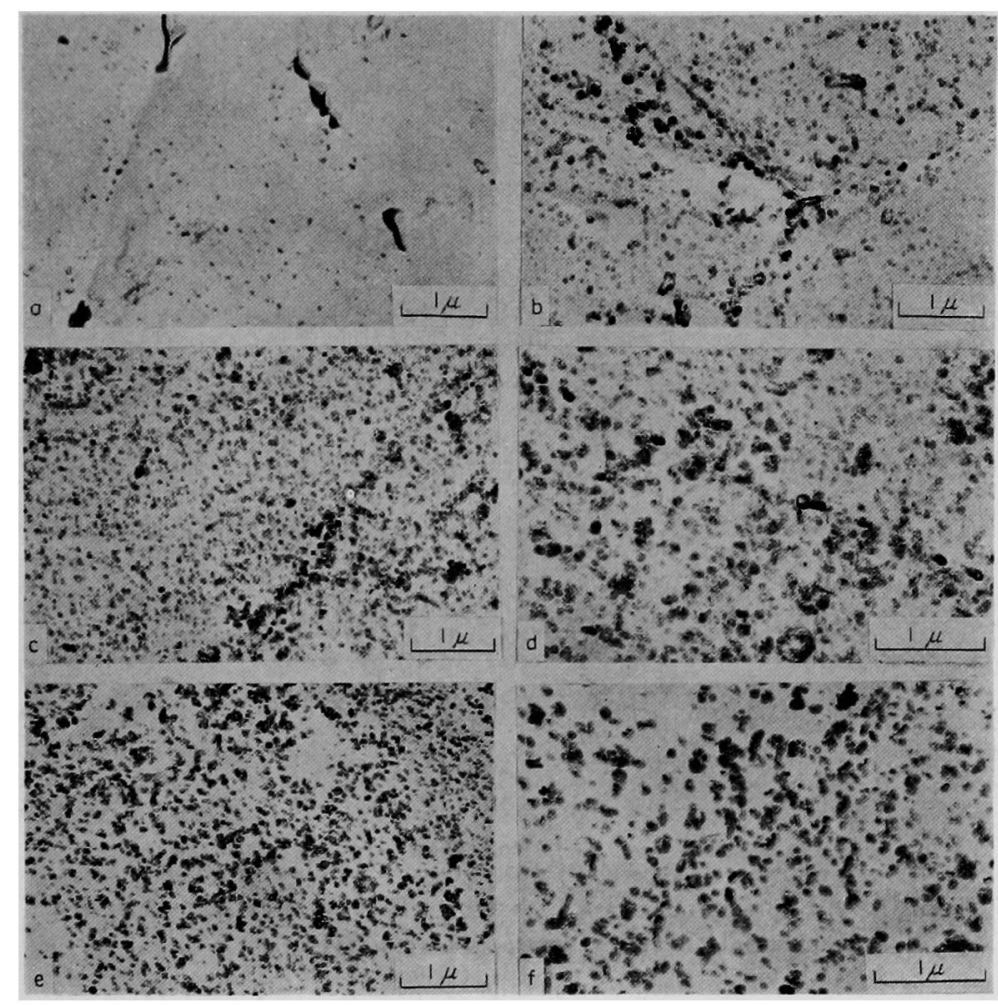
a) As hot rolled
b) $707^{\circ} \mathrm{C} \times 5 \mathrm{~min}$
c) $707^{\circ} \mathrm{C} \times 20 \mathrm{~min}$
d) $707^{\circ} \mathrm{C} \times 20 \mathrm{~min}$
e) $707^{\circ} \mathrm{C} \times 60 \mathrm{~min}$
f) $707^{\circ} \mathrm{C} \times 180 \mathrm{~min}$

Photo. 2. AlN precipitates in an Al-killed steel hot band during isothermal annealing (extraction replica).

果がなくなつて再結晶が進行するものと考えられる.

\section{3 抽出レプリカ}

実用アルキルド鋼の熱延板と, $1250^{\circ} \mathrm{C} \times 1 \mathrm{hr}$ の溶体 化処理後水焼入れした高純度 $\mathrm{Fe}-\mathrm{Al}-\mathrm{N}$ 合金板を, それ ぞれ $707^{\circ} \mathrm{C}$ で各種時間, ソルトバスで加熱し, 抽出レ プリカ法によりそれらの析出物の電子顕微鏡観察を行な つた．使用した実用アルミキルド鋼熱延板の化学成分を Table 2 に示す. 実用熱延板についての結果をPhoto. 2 に, 高純度 Fe-Al-N 合金についての結果を Photo. 3 に示す.

実用熱延板では， $707^{\circ} \mathrm{C} \times 5 \mathrm{~min}$ の焼鈍で，粒界，粒 内のいずれにも細かい析出物がみられる. $20 \mathrm{~min} の$ 焼鈍 で析出物の密度は増加する. $180 \mathrm{~min}$ では析出物は大き く明りようなものになる. 析出物の電子線回折の絬果を
Photo. 4 亿, 求めた面間隔の值を Table 3 に示す. 電 子線回折の結果より， $5 \mathrm{~min} ， 20 \mathrm{~min}$ でみられる析出物 と $180 \mathrm{~min}$ でみられる析出物とは異なつた構造のもの であることがわかる. $5 \mathrm{~min}, 20 \mathrm{~min}$ の焼鈍でみられる 析出物の電子線回沂像より求めた面間隔の值は, 花井,

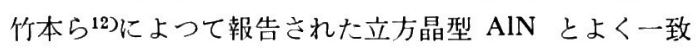
する. $180 \mathrm{~min}$ の焼鈍でみられる析出物は通常の六方晶 型 AIN である. 60 min では両方のまじつた電子線回 折像が得られる.

溶体化処理した高純度 $\mathrm{Fe}-\mathrm{Al}-\mathrm{N}$ 合金の板では, $707^{\circ}$ $\mathrm{C} \times 10 \mathrm{~min}$ の焼鈍でまず粒界に析出物がみられる. 30 minでは粒内にもみられるようになる.180 minでは析出 物は明りような形になる. 実用熱延板と比較して析出物 は大きく, 粗い。析出物の電子線回折像より求めた面閒 


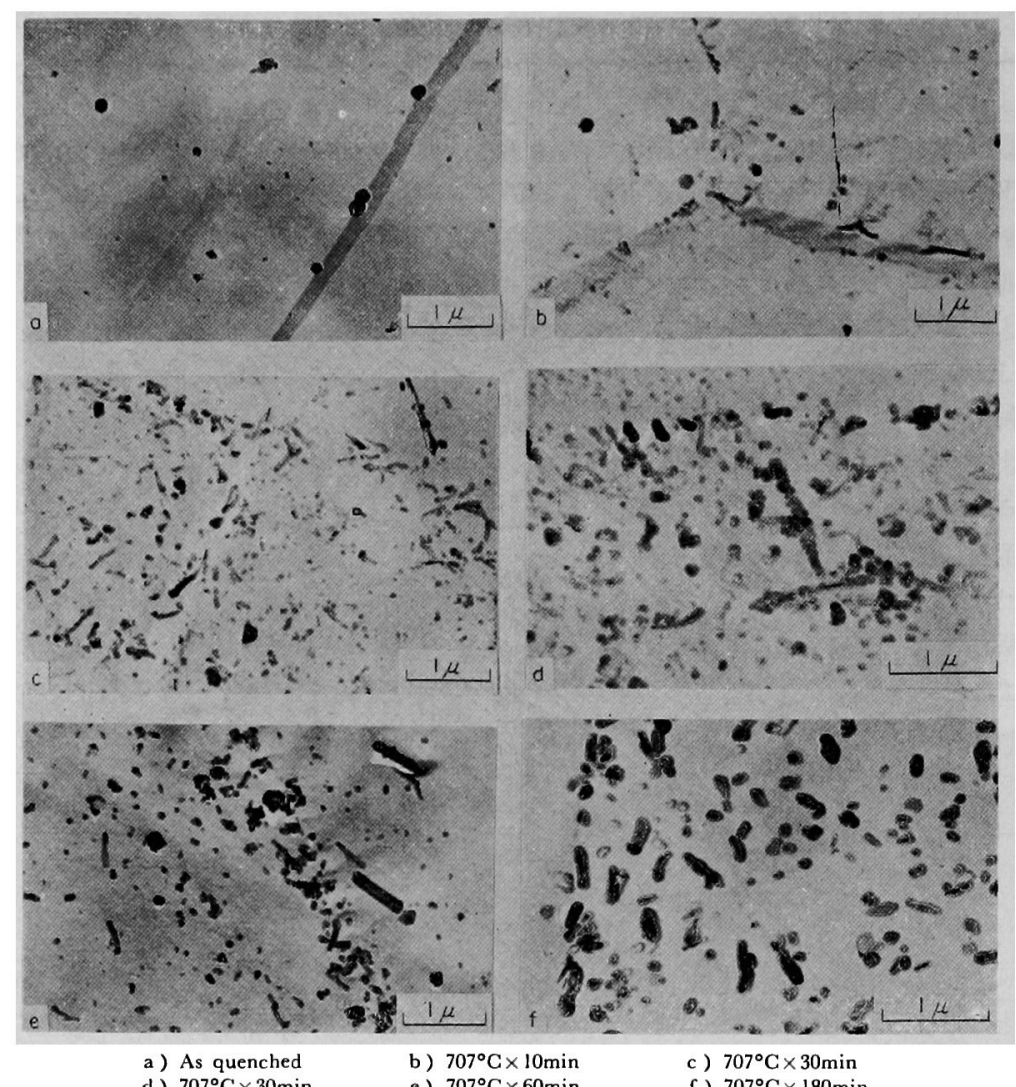
d) $707^{\circ} \mathrm{C} \times 30 \mathrm{~min}$
e) $707^{\circ} \mathrm{C} \times 60 \mathrm{~min}$
f) $707^{\circ} \mathrm{C} \times 180 \mathrm{~min}$

P'oto. 2. AlN precipitates in a high purity $\mathrm{Fe}-0 \cdot 09 \mathrm{Al}-\mathrm{N}$ alloy during isothermal annealing (extraction replica).

Table 3. Analysis of precipitates in an Al-killed steel hot band annealed isothermally.

\begin{tabular}{|c|c|c|c|c|c|}
\hline $707^{\circ} \mathrm{C} \quad 5 \mathrm{~min}$ & $707^{\circ} \mathrm{C} \quad 20 \mathrm{~min}$ & $707^{\circ} \mathrm{C} \quad 60 \mathrm{~min}$ & $707^{\circ} \mathrm{C} \quad 180 \mathrm{~min}$ & $\begin{array}{c}\text { AIN } \\
\text { ASTM 8-262 } \\
\text { (hexagonal) }\end{array}$ & $\begin{array}{c}\text { AlN } \\
\left.(\text { cubic })^{12}\right)\end{array}$ \\
\hline $\begin{array}{l}2 \cdot 50 \text { spot } \\
2 \cdot 39 \text { spot } \\
\\
2 \cdot 02 \mathrm{M} \\
1 \cdot 79 \mathrm{spot} \\
1 \cdot 58 \mathrm{~W} \\
1 \cdot 44 \mathrm{~W}\end{array}$ & $\begin{array}{l}2 \cdot 65 \text { spot } \\
2 \cdot 42 \text { spot } \\
2 \cdot 05 \mathrm{~S} \\
1 \cdot 56 \text { spot } \\
1 \cdot 45 \mathrm{~W}\end{array}$ & $\begin{array}{l}2 \cdot 70 \mathrm{~S} \\
2 \cdot 50 \text { spot } \\
2 \cdot 35 \text { spot } \\
2 \cdot 04 \mathrm{~S} \\
1 \cdot 84 \text { spot } \\
1 \cdot 56 \cdot \text { spot } \\
1 \cdot 43 \text { spot } \\
1 \cdot 32 \text { spot }\end{array}$ & $\begin{array}{l}2 \cdot 70 \mathrm{~S} \\
2 \cdot 52 \text { spot } \\
2 \cdot 36 \text { spot } \\
1 \cdot 84 \text { spot } \\
1 \cdot 56 \mathrm{Ml} \\
1 \cdot 41 \text { spot } \\
1 \cdot 35 \text { spot }\end{array}$ & $\begin{array}{lr}2 \cdot 70 & (100) \\
2 \cdot 49 & (60) \\
2 \cdot 372 & (70) \\
& \\
1 \cdot 829 & (20) \\
1 \cdot 557 \quad(30) \\
\\
1 \cdot 414 \quad(20) \\
1 \cdot 348 \quad(6) \\
1 \cdot 320(18)\end{array}$ & $\begin{array}{l}2 \cdot 34(\mathrm{~W}) \\
2 \cdot 024(\mathrm{~S}) \\
1 \cdot 428(\mathrm{M})\end{array}$ \\
\hline
\end{tabular}

隔の值を Table 4 に示す. $10 \mathrm{~min}$ の焼釚では回折線の 強度が非常に弱かつたが，六方晶型 AlN と推定された。 $30 \mathrm{~min}$ では析出物はほとえど六方晶型 AIN と同定され たが視里によつては立方晶型 AlN からのものと思われ る回折 spot がまじつている場合もあつた. このように 高純度 $\mathrm{Fe}-\mathrm{Al}-\mathrm{N}$ 合金では実用アルミキルド鋼における
ような明りような立方晶型 AIN は観察されなかつた・ 次に前述の再結晶分率を測定した高純度 Fe-Al-N 合 金の線試料（A）について, 同一方法による析出物の電 子频微鏡観察を行なつだ. $557^{\circ} \mathrm{C}$ で等温焼鈍した試料に ついての結果を Photo. 5 に示す. また Table 5 に面 間隔の測定結果を示す. $87 \mathrm{~min}$ の燒鈍で析出物がみら 


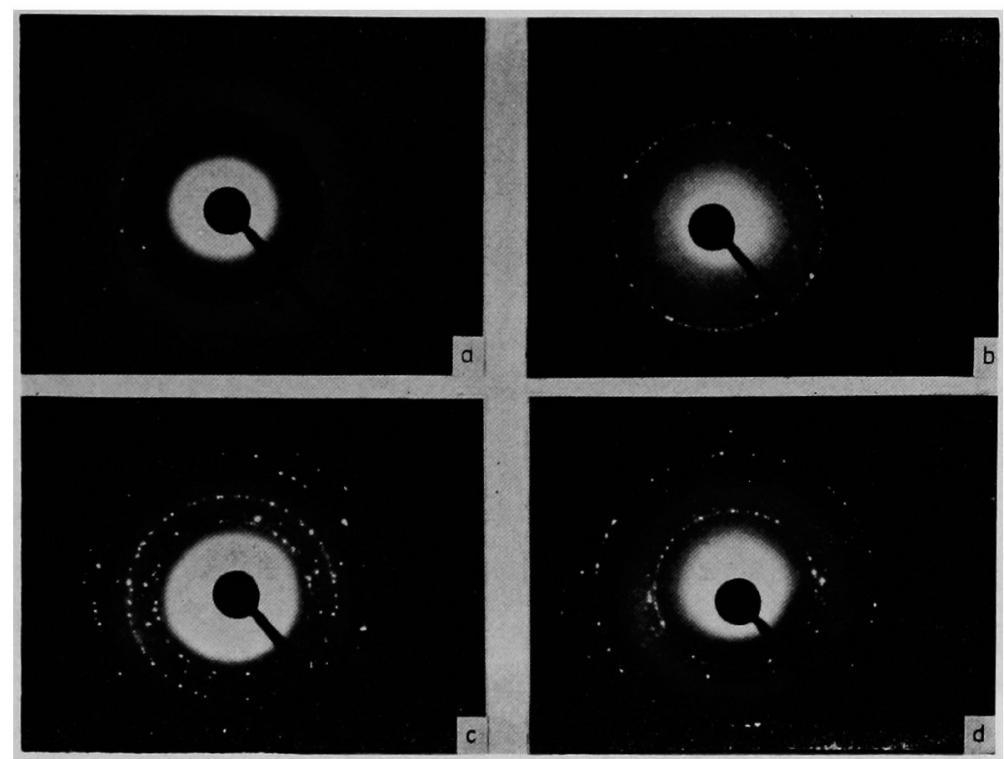

$\begin{array}{ll}\text { a) } 707^{\circ} \mathrm{C} \times 5 \mathrm{~min} & \text { b) } 707^{\circ} \mathrm{C} \times 20 \mathrm{~min} \\ \text { c) } 707^{\circ} \mathrm{C} \times 60 \mathrm{~min} & \text { d) } 707^{\circ} \mathrm{C} \times 180 \mathrm{~min}\end{array}$

Photo. 4. Diffraction patterns of precipitates in an Al-killed steel hot band.

Table 4. Analysis of precipitates in a ligh purity Fe-Al-N alloy annealed isothermally.

\begin{tabular}{|c|c|c|c|c|c|}
\hline $707^{\circ} \mathrm{C} \quad 10 \mathrm{~min}$ & $707^{\circ} \mathrm{C} \quad 30 \mathrm{~min}$ & $707^{\circ} \mathrm{C} \quad 60 \mathrm{~min}$ & $707^{-} \mathrm{C} \quad 180 \mathrm{~min}$ & $\begin{array}{c}\text { AlN } \\
\text { ASTM 8-262 } \\
\text { (lexagonal) }\end{array}$ & $\begin{array}{c}\text { AlN } \\
\left.\text { (cubic) }{ }^{12}\right)\end{array}$ \\
\hline $\begin{array}{l}2 \cdot 70 \text { sfet } \\
2 \cdot 49 \text { spot } \\
1 \cdot 53 \text { spot }\end{array}$ & $\begin{array}{l}2 \cdot 70 \mathrm{~S} \\
2 \cdot 49 \text { spot } \\
2 \cdot 37 \text { sput } \\
2 \cdot 19 \text { (spot) } \\
2 \cdot 01 \text { (spot) } \\
1 \cdot 83 \text { spot } \\
1 \cdot 56 \text { spot } \\
1 \cdot 41 \text { spot } \\
1 \cdot 34 \text { spot }\end{array}$ & $\begin{array}{l}2 \cdot 70 \text { spot } \\
2 \cdot 52 \text { spot } \\
2 \cdot 37 \text { spot } \\
2 \cdot 21 \text { spot } \\
1 \cdot 84 \text { spot } \\
1 \cdot 56 \text { spot } \\
1 \cdot 43 \text { spot } \\
1 \cdot 34 \text { spot }\end{array}$ & $\begin{array}{l}2 \cdot 65 \text { spot } \\
2 \cdot 31 \text { spot } \\
2 \cdot 32 \text { spot } \\
\\
1 \cdot 82 \text { spot } \\
1 \cdot 56 \text { spot } \\
1 \cdot 50 \text { spot } \\
1 \cdot 43 \text { spot } \\
1 \cdot 36 \text { spot }\end{array}$ & $\begin{array}{lr}2 \cdot 70 & (100) \\
2 \cdot 49 & (60) \\
2 \cdot 372 & (70) \\
& \\
1 \cdot 829 & (20) \\
1 \cdot 557 \quad(30) \\
\\
1 \cdot 414 \quad(20) \\
1 \cdot 348 \quad(6) \\
1 \cdot 320 \quad(18)\end{array}$ & $\begin{array}{l}2 \cdot 34(\mathrm{~W}) \\
2 \cdot 024(\mathrm{~S}) \\
1 \cdot 428(\mathrm{M})\end{array}$ \\
\hline
\end{tabular}

れるが回折像は得られなかつた. $270 \mathrm{~min}$ の焼鈍で析出 物からごく河い回折像が得られたが，これは多くの場合 六方品型AINによるものと推定された。視野によつて立 方晶型 AIN 飞相当する弱い回折 spot を得る場合があつ た. $430 \mathrm{~min} て ゙$ 析出物は明りようになり, 回折像もはつ きりしたものが得られる. これらは六方晶型AlN と同定 され, 立方晶型 $\mathrm{AlN}$ は観察されなかつた, $500 \mathrm{~min}$, $1000 \mathrm{~min}, 2040 \mathrm{~min}$ の焼鈍においても析出物の構造 はいずれも六方晶型 AIN であつた. Photo. 6 に $627^{\circ} \mathrm{C}$ における等温焼鈍の結果を示す. この温度では $30 \mathrm{~min}$ の焼鈍で不定形の析出物がみられ, 電子線回折の結果, 六方晶 AlN と立方晶 AlN とが混つたものであること
がわかつた. $100 \mathrm{~min}$ の焼鈍で析出物は六方晶のみにな り，490 min では明りような形になるが， $557^{\circ} \mathrm{C} に$ 比較 して析出物は粗大化している. $607^{\circ} \mathrm{C} \times 270 \mathrm{~min}, 657^{\circ} \mathrm{C}$ $\times 30 \mathrm{~min}$ で, $627^{\circ} \mathrm{C} \times 30 \mathrm{~min}$ と同様, 立方晶型 $\mathrm{AlN}$ と 六方晶型 AlN の混じつた回折像が得られた. $707^{\circ} \mathrm{C} \times$ $30 \mathrm{~min}$ では析出物は六方晶型 AlN であつた. これらの 結犱を Table 6 に示す. 以上の結果より, 本実験に使 用した高純度 Fe-Al-N 合金では，AINの析出は主に六 分晶型 AlN として起こり, 析出の初期に立方晶型AIN を観察する場合があつたが，これらは比較的すみやかに 六方晶型AINに变化するか，または消失するものである ことがわかつた. 


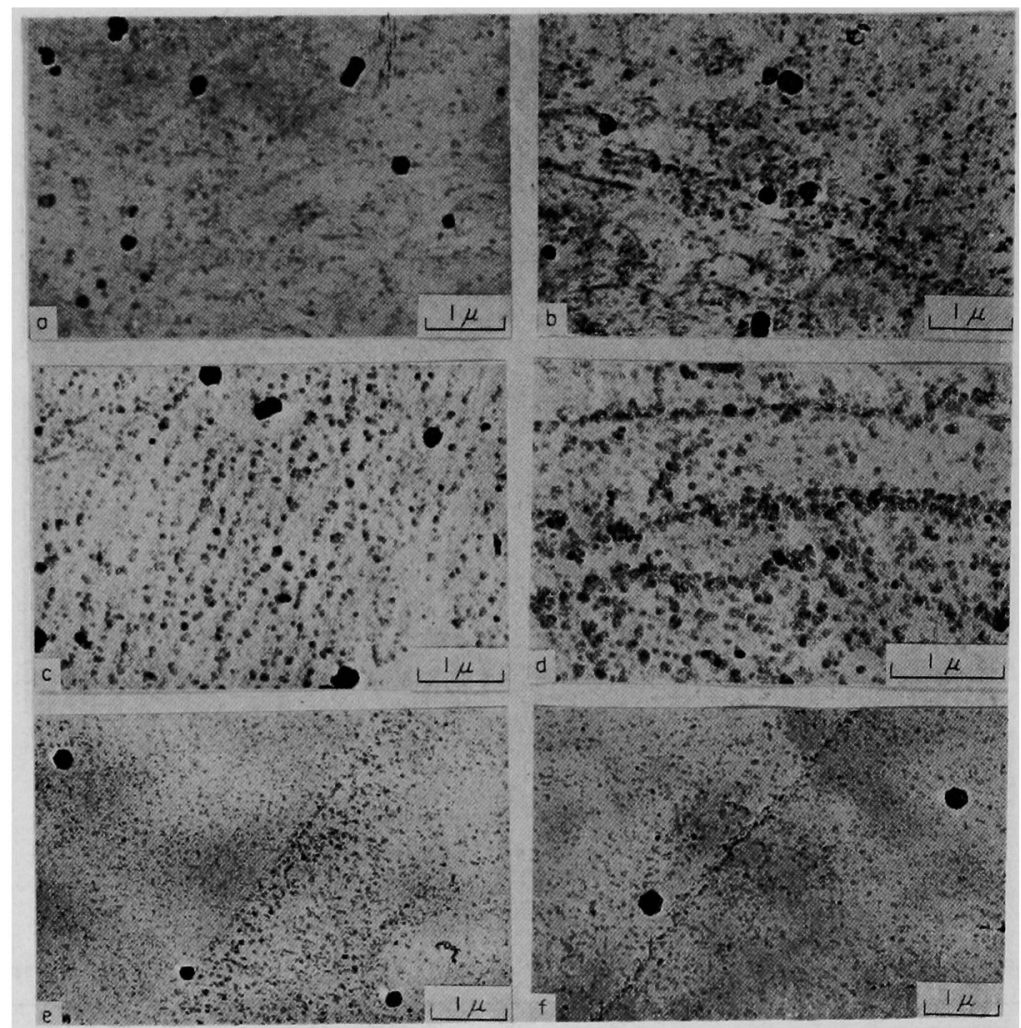
a) $557^{\circ} \mathrm{C} \times 130 \mathrm{~min}$
b) $557^{\circ} \mathrm{C} \times 270 \mathrm{~min}$
c) $557^{\circ} \mathrm{C} \times 500 \mathrm{~min}$
d) $557^{\circ} \mathrm{C} \times 500 \mathrm{~min}$
e) $557^{\circ} \mathrm{C} \times 1000 \mathrm{~min}$
f) $557^{\circ} \mathrm{C} \times 2040 \mathrm{~min}$

Photo. 5. AlN precipitates in a high purity $\mathrm{Fe}-0.09 \mathrm{Al}-\mathrm{N}$ alloy during isothermal annealing (extraction replica).

Table 5. Analysis of precipitates in a high purity $\mathrm{Fe}-\mathrm{Al}-\mathrm{N}$ alloy annealed isothermally.

\begin{tabular}{|c|c|c|c|c|c|c|}
\hline $\begin{array}{l}557^{\circ} \mathrm{C} \\
271^{\mathrm{min}}\end{array}$ & $\begin{array}{l}557^{\circ} \mathrm{C} \\
430 \mathrm{~min}\end{array}$ & $\begin{array}{l}557^{\circ} \mathrm{C} \\
500 \mathrm{~min}\end{array}$ & $\begin{array}{l}557^{\circ} \mathrm{C} \\
1000 \mathrm{~min}\end{array}$ & $\begin{array}{c}557^{\circ} \mathrm{C} \\
2040 \mathrm{~min}\end{array}$ & $\begin{array}{c}\text { AlN } \\
\text { ASTM 8-262 } \\
\text { (hexagonal) }\end{array}$ & $\begin{array}{c}\text { AlN } \\
\left(\text { cubic) }{ }^{12}\right)\end{array}$ \\
\hline $2 \cdot 52 \mathrm{VW}$ & $\begin{array}{l}2 \cdot 70^{-} \mathrm{M} \\
2 \cdot 52 \text { spot } \\
2 \cdot 36 \text { spot }\end{array}$ & $\begin{array}{l}2 \cdot 67 \mathrm{M} \\
2 \cdot 46 \mathrm{spot} \\
2 \cdot 32 \mathrm{~W}\end{array}$ & $\begin{array}{l}2 \cdot 70 \mathrm{~S} \\
2 \cdot 45 \mathrm{spot}\end{array}$ & $\begin{array}{l}2 \cdot 65 \mathrm{~S} \\
2 \cdot 41 \text { spot }\end{array}$ & $\begin{array}{ll}2 \cdot 70 & (100) \\
2 \cdot 49 & (60) \\
2 \cdot 372 & (70)\end{array}$ & $\begin{array}{l}2 \cdot 34(\mathrm{~W}) \\
2 \cdot 024(\mathrm{~S})\end{array}$ \\
\hline $1.53 \mathrm{VW}$ & & $1 \cdot 54 \mathrm{~W}$ & $\begin{array}{l}1.83 \text { spot } \\
1.55 \mathrm{M}\end{array}$ & $1 \cdot 56 \mathrm{M}$ & $1 \cdot 557(30)$ & 1. \\
\hline & $\begin{array}{l}1.42 \text { spot } \\
1 \cdot 33 \text { spot }\end{array}$ & & $\begin{array}{l}1 \cdot 44 \text { spot } \\
1 \cdot 35 \text { spot }\end{array}$ & $\begin{array}{l}1 \cdot 41 \text { spot } \\
1 \cdot 32 \text { spot }\end{array}$ & 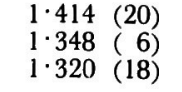 & \\
\hline
\end{tabular}

4. 考

察

\section{1 電気抵抗}

Fig. 1 の stage 1 の低下量は $0 \cdot 106 \mu \Omega \mathrm{cm}$ で固溶 $\mathrm{N}$ の電気抵抗寄与 $27 \cdot 7 \mu \Omega \mathrm{cm} / \mathrm{wt} \%$ 14)を用いて計算すると $38 \mathrm{ppm}$ のが転位にとらえられたことを示す. 溶体化
処理時の固溶 $\mathrm{N}$ 量は約 $60 \mathrm{ppm}$ であることを考元ると ${ }^{13)}$ この值が小さいのは，常温での伸線加工時に固溶Nの一 部はすでに歪時効により転位にとらえられているためと 思われる. 同一処理をした試料を $132^{\circ} \mathrm{C}$ の等温処理を 施して電気抵抗を測定した結果，抵抗の低下の総量は $0.087 \mu \Omega \mathrm{cm}$ であつた. したがつて Fig. 1 の stage 1 


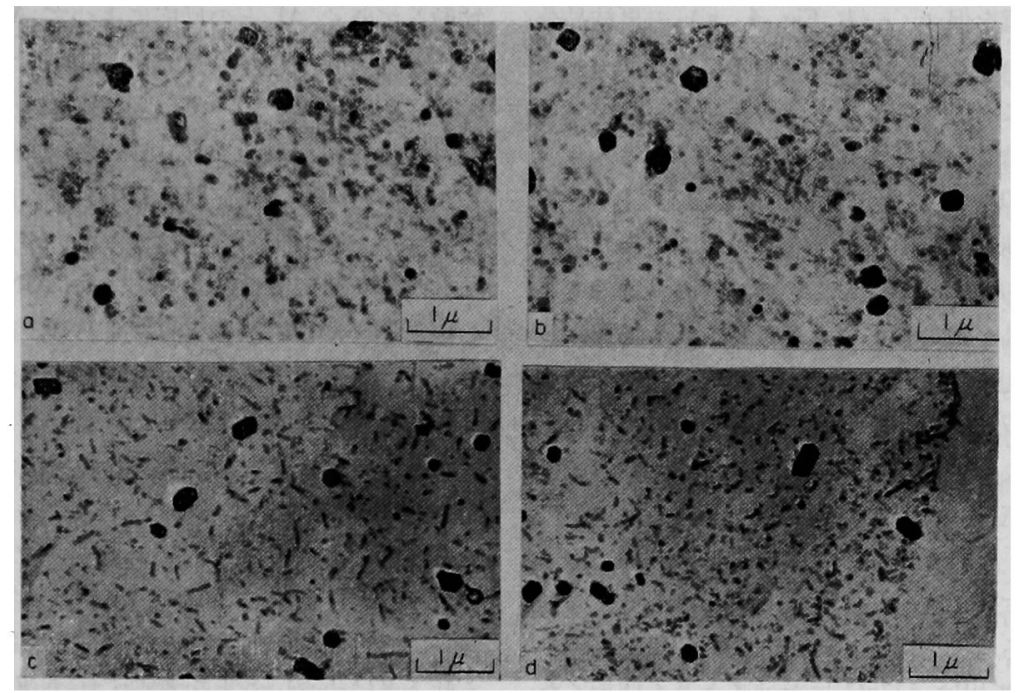
a) $627^{\circ} \mathrm{C} \times 30 \mathrm{~min}$
c) $627^{\circ} \mathrm{C} \times 490 \mathrm{~min}$
b) $627^{\circ} \mathrm{C} \times 30 \mathrm{~min}$
d) $627^{\circ} \mathrm{C} \times 490 \mathrm{~min}$

Photo. 6. AlN precipitates in a high purity $\mathrm{Fe}-0.09 \mathrm{Al}-\mathrm{N}$ alloy during isothermal annealing (extraction replica).

Table 6. Analysis of precipitates in a high puriy $\mathrm{Fe}-\mathrm{Al}-\mathrm{N}$ alloy

\begin{tabular}{|c|c|c|c|c|c|}
\hline $607^{\circ} \mathrm{C} \quad 270 \mathrm{~min}$ & $627^{\circ} \mathrm{C} \quad 30 \mathrm{~min}$ & $657^{\circ} \mathrm{C} \quad 30 \mathrm{~min}$ & $707^{\circ} \mathrm{C} \quad 30 \mathrm{~min}$ & $\begin{array}{c}\text { AlN } \\
\text { ASTM 8-262 } \\
\text { (hexagonal) } \\
\end{array}$ & $\underset{\left(\text { cubic) }{ }^{12}\right)}{\text { AlN }}$ \\
\hline $\begin{array}{l}2 \cdot 70 \text { spot } \\
2 \cdot 55 \text { spot } \\
2 \cdot 43 \text { spot } \\
2 \cdot 01 \mathrm{M} \\
1 \cdot 56 \text { spot } \\
1 \cdot 44 \text { spot } \\
1 \cdot 40 \text { spot }\end{array}$ & $\begin{array}{l}2 \cdot 65 \mathrm{M} \\
2.46 \text { spot } \\
2 \cdot 38 \text { spot } \\
2 \cdot 03 \mathrm{M} \\
1 \cdot 56 \text { spot } \\
1 \cdot 42 \text { spot } \\
1 \cdot 32 \text { spot }\end{array}$ & $\begin{array}{l}2 \cdot 70 \mathrm{M} \\
2 \cdot 53 \mathrm{spot} \\
2 \cdot 40 \text { spot } \\
2 \cdot 04 \text { spot } \\
1 \cdot 85 \text { spot } \\
1 \cdot 54 \text { spot } \\
1 \cdot 41 \text { spot } \\
1 \cdot 33 \text { spot }\end{array}$ & $\begin{array}{l}2 \cdot 70 \mathrm{~S} \\
2 \cdot 52 \text { spot } \\
2 \cdot 43 \text { spot } \\
1 \cdot 83 \text { spot } \\
1 \cdot 54 \text { spot } \\
1 \cdot 35 \text { spot }\end{array}$ & $\begin{array}{lr}2 \cdot 70 & (100) \\
2 \cdot 49 & (60) \\
2 \cdot 372 & (70) \\
& \\
1 \cdot 829 & (20) \\
1 \cdot 557 & (30) \\
& \\
1 \cdot 414 \quad(20) \\
1 \cdot 348 & (6) \\
1 \cdot 320 & (18)\end{array}$ & $\begin{array}{l}2 \cdot 34(\mathrm{~W}) \\
2 \cdot 024(\mathrm{~S}) \\
1 \cdot 428(\mathrm{M})\end{array}$ \\
\hline
\end{tabular}

の終わる $150^{\circ} \mathrm{C}$ では固溶 $\mathrm{N}$ はほとえど転位にとらえら れたものと考えられる. stage 2 は加工していない試料 に比較して約 $100^{\circ} \mathrm{C}$ 低い温度から起こつているが13), これは加工によつて析出のための site の数が増加したた めと考えられる. この stage 2 の始まる $450^{\circ} \mathrm{C}$ までに 電気抵抗はわずかずつ約 $0.01 \mu \Omega \mathrm{cm}$ の量だけ増加す る. 加工していない試料では stage 2 の始まるまでには それ以前に析出した鉄の䇪化物は完全に再固溶寸る. 高 村ら ${ }^{15)}$ は $20 \%$ の引張り変形を加えた純鉄の試料を等時 焼鈍したときの電気抵抗の低下は, 回復初期の $440^{\circ} \mathrm{C}$ ま ではわずかに約 $0.01 \mu \Omega \mathrm{cm}$ の程度であり, $440^{\circ} \mathrm{C}$ 以上 の回復後期の subboundary の形成時および再結晶時に 主におこることを報告している、したがつて本実験にお けるわずかな電気抵抗の増加は, 回復初期の電気抵抗の
低下と Nの再固溶にともなう上昇との重なりあつたもの と考えられるが，上述のごとく前者の抵抗の低下はわず かなものと考光られので, stage 2 の始まるまでの $\mathrm{N}$ の再固溶は少量で, 大部分転位にとらえられたままであ ると考えられる.したがつてつぎの stage 2 においては AINの析出が起こつていると思われるが，この加工した 試料における AlN の析出の機構は, 溶体化処理した試 料をそのまま焼鈍するときのように $\mathrm{Al}$ と $\mathrm{N} か ゙$ 同時に拡 散して AIN を作る機構よりも，すでに転位にとらえら れた $\mathrm{N}$ ，拡散してくる $\mathrm{Al}$ との反応によつて転位線上 に AIN が生成される機構が支配的であろう.

Fig. 2 の等温焼鈍曲線においては, いずれの温度にお いても, $1 \mathrm{~min}$ 以内の短時間の焼鈍により, Fig. 1 の等 時焼鈍の stage 1 に対応するごとき電気抵抗の低下があ 
り，その後一定值を保つ. 一方 Fig. 4 a) の再結晶分 率の測定よりわかるごとく，等温烧鈍のごく初期より， それぞれの温度に対応してある量の再結晶が起こつてい る.これらの再結晶分率は焼鈍温度が高いほど大きく, また各温度で $100 \mathrm{~min}$ 以上に至るまで変化しない. 電 気抵抗がごく初期の低下の後, かなりの期間一定值を保 つことは, この初期の低下に対応して，Nの正時効とと もに回復·再結晶が起こつていると考えられる. Fig. 2 の電気抵抗の最初の低下は, Fig. 4 a)の再結晶分率の測 定より考えて, $577^{\circ} \mathrm{C}$ 以下の温度での等温焼鈍の場合に はNの歪時効による低下が大部分であり，607 $\mathrm{C}$ 以上で は再結晶による抵抗の低下が支配的と思われる. 以上の ことを考虙して, より長時間側で大きく抵抗值が減少す る stage について考察しよう.この stage は AlN の析 出に対応しているものと考えられる. $607^{\circ} \mathrm{C}$ 以上の烧鈍 温度で, AlN の析出は $577^{\circ} \mathrm{C}$ におけるよりもはやくな らず，むしろおそくなる． $607^{\circ} \mathrm{C}$ 以上の焼鈍では加工組 絨は大部分再結晶しているので, AIN の析出反応は溶体 化処理した試料を $\alpha$ 域で等温焼鈍するとき之同様の機楧 が支配的と考えられる. 一方 $577^{\circ} \mathrm{C}$ 以下においては加 工組織中における析出挙動, すなわ方等時焼鈍における $\mathrm{AlN}$ の析出挙動と同様の転位にとらえられた $\mathrm{N}$ とこに
拡散してゆく $\mathrm{Al}$ との反応によつて AlN が生成される 機栱が支配的と考えられる.このように等温焼鈍では AIN の析出機構は 2 つの温度領域にわけられる. この AlN の析出の stage の前には前述の最初の stage があ るので，この stage だけとり出して，前報で行なつたよ うな方法で解析することができない.したがつてつぎの ような方法で解析を試みた. この AlN の析出の stage の後半では AIN は核生成を終わり，成長の段階に移つ ていることが考えられる.とくに低温側では転位にとら

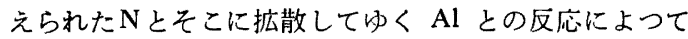
AINができる機秒を述べた．この機棒が支配的であり， Al の拡散が律速過程であるとすれば，この反応は一次 反态と考えられる．また Fig. 4 a) の再結晶分率の測 定より AlN 析出の $90 \%$ 以上が進んでから残りの未再 結晶部の再結晶が進むことおよび電気抵抗の再結晶によ る低下量は小さいことを考虑すれば Fig. 2 の AlN の 析出に対応する stage はほとんど AIN の析出に原因す ると考えられる. したがつて Fig. 2 の電気抵抗曲線で, ある時間 $\left(t_{1}\right)$ 後より一次反応が起こるとすると

$$
\begin{aligned}
& d\left(\rho-\rho_{f}\right) / d t=-K\left(\rho-\rho_{f}\right) \\
& \text { ここで } \quad K=K_{0} \exp (-H / R T) \\
& \rho: t \text { 時間後の電気抵抗 }
\end{aligned}
$$

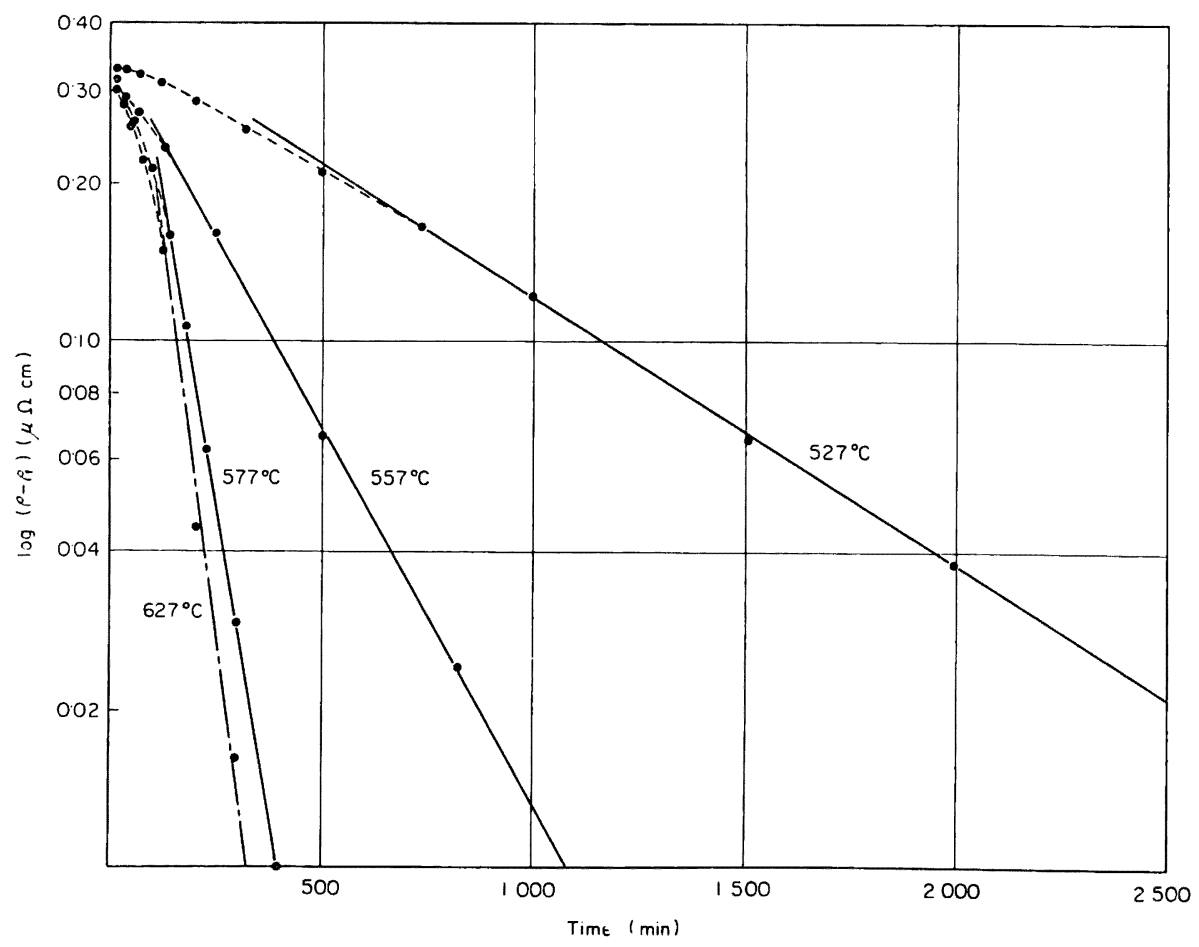

Fig. 5. " $\log \left(\rho-\rho_{\mathrm{f}}\right)$ vs. time" plotting from isothermal annealing curves in Fig. 2 . 


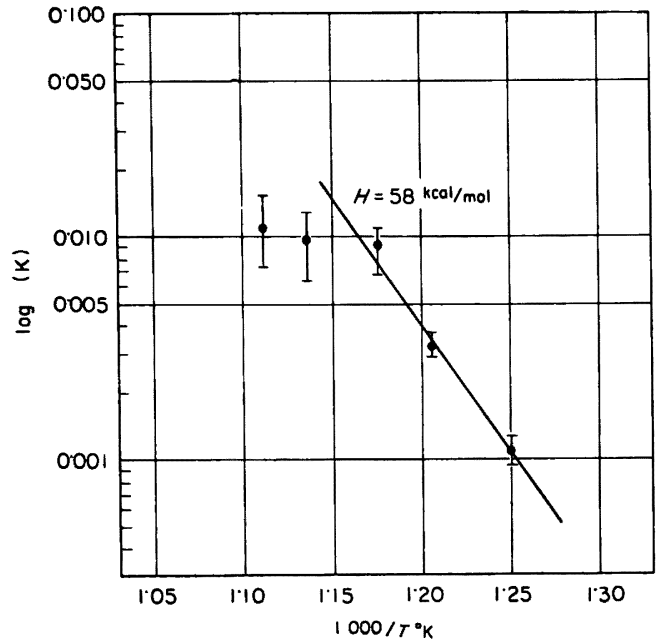

Fig. 6. Determination of activation energy by Arrhenius plotting.

$\rho_{f}:$ 一次反応終了時の電気抵抗

積分すれば $\ln \left(\rho-\rho_{f}\right)=-K t+A$

$$
A=-K t_{1}+\ln \left(\rho_{1}-\rho_{f}\right)
$$

$\rho_{1}$ : 一次反応開始時 $\left(t_{1}\right)$ の電気抵抗

ゆえに $\ln \left(\rho-\rho_{f}\right)$ と $t$ との間の関係をとると直線とな

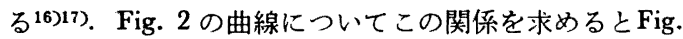
5 が得られる. $527^{\circ} \mathrm{C}$ では約 $500 \min$ から $557^{\circ} \mathrm{C}, 577$ ${ }^{\circ} \mathrm{C}$ では約 $100 \mathrm{~min}$ 程度から直線にのるのがわかる. こ れより Fig. 2 の電気抵抗曲線は，反応がある時間進ん だ後では一次反応になることがわかる．直線の勾配より $K$ の值を求め, これらと $1 / T\left({ }^{\circ} \mathrm{K}\right)$ の関係より反応の 活性化エネルギーを求めた. その結果をFig. 6 に示す. $527^{\circ} \mathrm{C}, 557^{\circ} \mathrm{C}, 577^{\circ} \mathrm{C}$ を結ぶ直線より活性化エネルギ 一として $58 \mathrm{kcal} / \mathrm{mol}$ が得られた. 加工していない試 料で, cross cut 法で得られた活性化エネルギーとはや や異なつた值であるが13，本方法はかなりの誤差をとも なうことを考虑すれば，この值はやはり $\alpha$ 鉄中でのAlの 拡散の活性化エネルギーを示すものと考えられる. 607 ${ }^{\circ} \mathrm{G}, 627^{\circ} \mathrm{C}$ の場合も反応の後半では Fig. 5 で示すよ うにほぼ直線関係が得られる。 これらの温度では AlN の析出の前に 再結晶が起こるため, 歪のない母相での AIN の析出とみなせ, 直線関係が得られるのは, 固溶 $\mathrm{Al}$ 量が固溶 $\mathrm{N}$ 量より多いこの試料では前報で示したように 反応は近似的に一次反応で示されるためであろう ${ }^{13)}$. ま た Fig. 5 で電気抵抗変化が一次反応として直線にのる までにはある時間を必要とするが，これは核生成のため の潜伏期間および核生成に起因するものと思われる.

\section{2 抽出レプリカ}

Fig. 7 に電気抵抗曲線と再結晶分率との関係および抽 出レプリカによる析出物の同定の結果を $557^{\circ} \mathrm{C}$ と 627 ${ }^{\circ} \mathrm{C}$ の場合について示した. $557^{\circ} \mathrm{C}$ における等温燒鈍で は，析出物はほとんど六方晶型 AlN であつた. したが つて前述の一次反応表示の 可能な領域は六方晶型 AIN の析出に対応しているものと考元られる. $627^{\circ} \mathrm{C} \times 30$ $\min$ の焼鈍で，六方晶型 AlN に混じつて，立方晶型 AIN によると考えられる明りような回折像を得たが, 100 min では六方晶型AINのみとなり, 電気抵抗が一定 值を示す $500 \mathrm{~min}$ ではやはり六方晶型 AIN 以外のもの は観察されなかつた．他の温度でも立方晶型AINは析出 の初期に観察され，電気抵抗の低下の後半では六方昆型 AINが析出しているように思われる. すなわち立方晶型

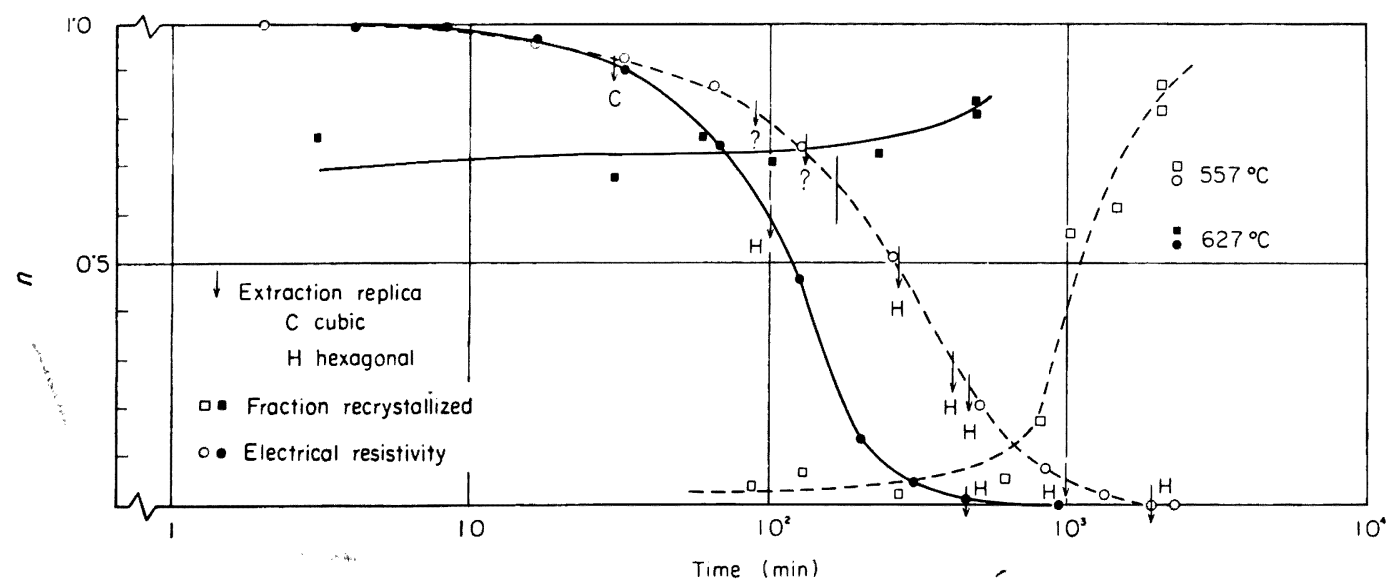

Fig. 7. Normalized resistivity change, fractions recrystallized, and analysis of precipitates for specimen $A$. 
AINは析出の初期に析出し, 比較的すみやかに六方晶型 AlNに変化し, AlNは六方晶型AlNとして成長するよう である。このように本実験に用いた高純度 Fe-Al-N 合 金において，実用熱延板におけるほど安定した立方晶型 AlN が観察されなかつたのは, 不純物の影響, 固溶 $\mathrm{Al}$ 量と $\mathrm{N}$ 量の割合の影響, 結晶粒度の影響などが考えられ るが，いまのところ原因は明らかでない.

Fig. 7 の AlN の析出に対応する電気抵抗の低下と再 結晶分率の変化から明らかなように析出が $90 \%$ 前後進む までは再結晶の進行は完全に阻止されている. 上述のご とくこの間に析出する AlN の形態はほとんど六方晶型 であるので，本実験に用いた高純度 $\mathrm{Fe}-\mathrm{Al}-\mathrm{N}$ 合金にお いては, AlNの再結晶抑制効果はその形態とは関係なく 微細な AlN の析出物が転位線上に析出することによる と考えられる.

\section{5. 結 言}

加工された $\alpha$ 鉄中の AIN の析出を不純物の影響をう けることなく純粋にしらべることを目的にして研究を行 なつた.すなわち帯域精製した高純度鉄を素材にして， 高純度の $\mathrm{Fe}-\mathrm{Al}-\mathrm{N}$ 合金を作り, 溶体化処理後常温で伸 線加工した試料を $\alpha$ 域で焼鈍して AlN を析出させ, そ の変化を主に電気抵抗および電䊗観察によつて調べつぎ の結果を得た.

1) 試料を等時焼鈍，等温焼鈍して電気抵抗の測定を 行ない AlN の析出に対応する stage を観察した. $10^{\circ} \mathrm{C}$ -10 min の等時焼鈍では AIN の析出の stage は $450^{\circ}$ $\sim 620^{\circ} \mathrm{C}$ 間にあり, 加工しない場合に比較して約 $100^{\circ} \mathrm{C}$ 低温側にずれている.この場合Nは低温で雪時効によつ て転位にとらえられ，焼鈍温度が上昇しても母相への再 固溶がなく，とらえられた $\mathrm{N}$ と拡散してきた $\mathrm{Al}$ との反 応によつて AlN が生成されるものと考えられる.

2) $527^{\circ} \sim 627^{\circ} \mathrm{C}$ の範囲で等温焼鈍によつて電気抵抗 変化を測定した. $607^{\circ} \mathrm{C} て ゙ は 577^{\circ} \mathrm{C}$ よりも析出はむしろ おそくなる. 再結晶分率の測定結果より，この温度以上 ではAINの析出が起こる前に再結晶が数 $10 \%$ 進行して いるのがわかつた. 析出 site が少なくなるため AlN の 析出はおそくなるものと考えられる.

3 ) 等温焼鈍曲線はある反応時間の後は一次反応とし て表示でき,一次反応における勾配と $1 / T\left({ }^{\circ} \mathrm{K}\right)$ の関係 は $577^{\circ} \mathrm{C}$ 以下では直線関係となり反応の活性化エネル ギーとして $58 \mathrm{kcal} / \mathrm{mol}$ が得られた. これは加工組織 中での AlN の析出も $\alpha$ 鉄中での $\mathrm{Al}$ の拡散によつて律 速されていることを示すものと思われる.
4) 再結晶分率の測定から，等温焼鈍では，各温度に対 して最初の数 min である量の再結昆が起こり, AlN の 析出が起こつている䦐再結晶は完全に抑えられることが わかつた. 抽出レプリカ法による析出物の観察から，こ の抑制効果は析出物の形態に関係なく, 微細なAINが転 位線上に析出することによるものと考えられる.

5 ) 析出物の抽出レプリカ法による電顕観察の結果, 実用アルミキルド鋼熱延板を $707^{\circ} \mathrm{C}$ で等温焼鈍したと き, 花井, 竹本らの報告のごとく ${ }^{12}$ 通常の六方晶型 $\mathrm{AlN}$ が析出する前に, 立方晶型AINが観察された. しかし本 実験で用いた高純度 Fe-Al-N 合金においては, 電気抵 抗の低下は主に六方晶型 AlN の析出に対応し，初期に 立方晶型 AIN が観察されたが，実用熱延板におけるほ ど安定には存在しないようである.この原因には不純物 の影郘, 固溶 $\mathrm{Al}$ 量と $\mathrm{N}$ 量の割合の影響, 結晶粒度の影 響などが考えられるが今回の実験では明らかではない。

最後に本研究を進めるにあたりご指導いただいた当社 浅田基礎研究所所長浅田常三郎博士に厚く謝意を表しま す.

\section{文献}

1) $W . C$. Leslie, $R . L$. Richett, $C . L$. Dotoson, and $C . S$. Walton: Trans. ASM, 46(1954), p. 1470

2) H.R. Goodenow: Trans. ASM, 59(1966), p. 804

3 ) J. T. Michalak and $R$. D. Schoone: Trans. Met. Soc. AIME, 242(1968), p. 1149

$4)$ 阪本：日本金属学会誌，34(1970), p. 71

5 ) 花井, 秋末：日本金属学会誌，32(1968), p. 345

6 ）音谷, 形浦: 日本金属学会誌, 33(1969), p. 742

7 ) 市山, 小泉, 吉田, 渡辺, 西海: 鉄と鋼, 55 (1969)， p. 1229

8 ) 阿部，鈴木：鉄と鋼，56(1970), p. 869

9 ) 市山, 吉田, 中川, 江島, 松村: 鉄と鋼, 56 (1970), p. 1726

10) 白岩, 寺崎, 小玉: 日本金属学会誌, 35(1971), p. 20

11）松阔，寺崎：日本鉄鋼協会第81回予稿，57 (1971)，S 276

12) 花井, 竹本, 水山, 佐直: 鉄と鋼, $57(1971)$, p. 386

13）八木, 福塚, 小川: 鉄と鋼, $57(1971)$, p. 978

14) $H$. Wagenblast and $S$. Arajs: Physica Status Solidi, 26(1968), p. 409

15) $J$. Takamura, $I$. Takahashi, and $M$. Amano: Trans. ISIJ, 9(1969), p. 217

16) $K . J$. LAIDLER: 化学反応速度論 I (高石訳), p.8 [産業図書]

17）吉田：日本鉄鋼協会第81回予稿 57 (1971), S 272 